\title{
Pseudomonas plecoglossicida as a novel bacterium for phosphate solubilizing and indole-3-acetic acid-producing from soybean rhizospheric soils of East Java, Indonesia
}

\author{
MELI ASTRIANI ${ }^{1,2}$, SITI ZUBAIDAH $^{1, \boldsymbol{v}}$, ABDUL LATIEF ABADI ${ }^{3}$, ENDANG SUARSINI ${ }^{1}$ \\ ${ }^{1}$ Department of Biology, Faculty of Mathematics and Natural Sciences, Universitas Negeri Malang. Jl. Semarang No. 5, Malang 65145, East Java, \\ Indonesia. Jl. Semarang 5, Malang 65145, East Java, Indonesia. Tel.: +62-341-552180. Fax.: +62-341-552180, `email: siti.zubaidah.fmipa@um.ac.id, \\ meliastriani.g201@gmail.com \\ ${ }^{2}$ Department of Biology Education, Faculty of Teacher Training and Education, Universitas Muhammadiyah Palembang. Jl. Jend. Ahmad Yani 13 Ulu, \\ Palembang 30116, South Sumatra, Indonesia. \\ ${ }^{3}$ Departement of Pests and Plant Diseases, Faculty of Agriculture, Universitas Brawijaya. Jl. Veteran, Malang 65145, East Java, Indonesia
}

Manuscript received: 11 November 2019. Revision accepted: 17 January 2020.

\begin{abstract}
Astriani M, Zubaidah S, Abadi AL, Suarsini E. 2020. Pseudomonas plecoglossicida as a novel bacterium for phosphate solubilizing and indole-3-acetic acid-producing from soybean rhizospheric soils of East Java, Indonesia. Biodiversitas 21: 578-586. The use of synthetic fertilizers to grow soybean (Glycine max (L.) Merrill) in a long time, can increase the risk of environmental damage. Therefore, the current study aimed to find phosphate solubilizing bacteria that can produce indole-3-acetic acid (IAA) hormone to minimize the use of chemical fertilizers. Superior isolates selected through characterization of phosphate solubilization activity on Pikovskaya medium, screening of IAA producing bacteria, quantitative estimation of phosphate solubilizing activity using a spectrophotometer, hypersensitivity assay, antagonist within isolate assay, and molecular identification of selected bacterial isolates using $16 \mathrm{~S}$ rRNA sequencing with primer forward $63 \mathrm{f}$ and primer reverse $1387 \mathrm{r}$. Among the isolated bacteria, isolate Arj8 showed the highest phosphate solubilizing activity and IAA production. Molecular identification indicated that isolate Arj8 shared $100 \%$ similarity with Pseudomonas plecoglossicida. The highest phosphate solubilizing activity (75.39 mg/L) and IAA production (38.89 ppm) recorded on day-3. Multiple potentialities of $P$. plecoglossicida as phosphate solubilizing and IAA producing bacterium are a novel finding in the development of bioinoculants as bio-fertilizers that can reduce dependency on synthetic chemical fertilizers.
\end{abstract}

Keywords: Pseudomonas plecoglossicida, phosphate solubilization, rhizobacteria, rhizosphere soybean

\section{INTRODUCTION}

East Java is one of Indonesia's soybean [Glycine max (L.) Merrill] largest producer with high levels of selfsufficiency (Zainuri et al. 2015; Hasan et al. 2015; Putra et al. 2017). Statistics Indonesia (2016) reported that $35 \%$ or 344.99 thousands of tons of the total soybean production in 2015 (963.18 thousands of tons) originated from East Java. Fertilization is one of the determining factors of soybean productivity. Synthetic chemical fertilizers such as NPK, urea, and TSP have used as nitrogen, phosphate, and potassium supply for soybean (Kristanti et al. 2017). However, the use of these chemical fertilizers can bring a negative impact on soil fertility by leaving hazardous residues to the surrounding environment (Kumar 2014). The use of synthetic phosphate fertilizers can be minimized by administering phosphate solubilizing bacteria (PSB) into the soil. PSB plays a key role in the mobilization and transformation of phosphate underground. The benefits of PSB as biofertilizers are alternatives to solving the phosphate availability issue for plants (Wei et al. 2017).

Even though soil contains a large amount of phosphorus, its availability for plants is very low because phosphorus can easily react with other compounds such as iron, aluminum, and calcium to form sediments (Weil and Brady 2017). The availability of phosphate in the soil can increase with the help of soil microbes (Wei et al. 2017). Rhizospheric soils contain more abundant microbes compared to ordinary soils due to the release of root exudates that can attract microorganisms ( $\mathrm{Li}$ et al. 2016). Root exudates are plant metabolites secreted by the roots of living plants. Root exudates such as isoflavones play a crucial role in biological processes, including nutrient absorption, plant defenses, and signaling for rhizospheric bacteria (Tsuno et al. 2018). During phosphate deficiency, plant root exudates determine changes in the concentration of metabolites produced by rhizobacteria. In mycorrhiza, metabolites produced include phosphatase enzyme which plays a vital role in the release of organic acids in the soil (Tawaraya et al. 2014).

Bacteria that inhabit and colonize plant roots are called plant growth promotion rhizobacteria (PGPR) (Singh 2018). PGPR serve an important function to improve plant growth through various mechanisms including producing phosphatase enzymes to support mineralization of phosphate in soil (Hungria et al. 2015; Fallo et al. 2015) and synthesizing natural compounds as plant growth promoters such as indole acetic acid (IAA) (Li et al. 2018; Qin and Huang 2018). IAA hormone can regulate many aspects of plant growth and development, cell division, and cell elongation (Majda and Robert 2018) and initiates lateral root formation (Jing and Strader 2019). However, 
applications of synthetic IAA harmful for plants. Compared to other types of synthetic hormones such as naphthalene acetic acid (NAA) 2,4-D and gibberellic acid (GA), IAA provoked the highest cytotoxic reactions (Solomon and Bradly 2014). An alternative to reducing the use of synthetic compounds is to replace it with natural compounds.

Indole acetic acid (IAA) is the most common and most active hormone found in nature. Around $80 \%$ of IAA produced by microbes that live around plant roots can be used to stimulate plant growth (Spaepen and Vanderleyden 2011; Glick 2012). This study aimed to isolate phosphate solubilizing bacteria that can also produce IAA hormone from soybean rhizospheres in East Java. The results of this study expected to provide insights into the development of bio inoculants that can serve as eco-friendly, effective, and efficient fertilizer for plants in the future.

\section{MATERIALS AND METHODS}

\section{Area study}

The current study was conducted from November 2018 to April 2019 at the Microbiology Laboratory of Faculty of Mathematics and Natural Sciences of Universitas Negeri Malang, Indonesia. Samples of the rhizospheric soybean soil were collecting from soybean plantations in Binangun Village, Blitar Regency, East Java. The GPS data from the sampling location (S $8{ }^{\circ} 11^{\prime} .38 .9$ E $\left.112^{\circ} \quad 20{ }^{\prime} 03.6\right)$ (https://www.google.co.jp/maps).

\section{Materials}

A laminar airflow, an autoclave, an Erlenmeyer flask, an oven, a hot plate, a bunsen burner, a spatula, an incubator, a shaker, a spectrophotometer, a petri dish, a micropipette, a microtube, a microscope, a centrifuge, a $1 \mathrm{~mL}$ syringe, and a digital camera were the tools used in this study. Materials used were soybean rhizospheric soil samples, Nicotiana tobaccum L., alcohol $70 \%$, primer $63 \mathrm{~F}$ and $1387 \mathrm{R}$, nutrient broth (NB) medium, nutrient agar (NA) medium, Pikovskaya medium containing $10 \mathrm{~g}$ glucose; $\mathrm{Ca}_{3}(\mathrm{PO} 4)_{2}, 5$ g; $\left(\mathrm{NH}_{4}\right)_{2} \mathrm{SO}_{4}, 0,5 \mathrm{~g} ; \mathrm{NaCl} \mathrm{0,2} \mathrm{g} ; \mathrm{MgSO}_{4} .7 \mathrm{H}_{2} \mathrm{O}, 0,1 \mathrm{~g} ; \mathrm{KCl}$, $0,2 \mathrm{~g}$; yeast extract $0,5 \mathrm{~g} ; \mathrm{MnSO}_{4} \cdot \mathrm{H}_{2} \mathrm{O}, 0,002 \mathrm{~g}$; $\mathrm{FeSO}_{4} .7 \mathrm{H}_{2} \mathrm{O}, 0,002 \mathrm{~g}$ (Nautiyal, 1999); Salkowski reagent $\left(150 \mathrm{ml} \mathrm{H}_{2} \mathrm{SO}_{4}, 7,5 \mathrm{ml} \mathrm{FeCl}{ }_{3} \cdot 6 \mathrm{H}_{2} \mathrm{O} 0,5 \mathrm{M}\right.$, and $250 \mathrm{ml}$ sterile aqua dest), and L-Tryptophan (Gang et al. 2019).

\section{Procedures}

\section{Sample collection}

Soil sampling carried out using a composite method where soil samples were collecting from 3 points around the roots of soybean plants with a depth of $5-10 \mathrm{~cm}$. A total of 100 grams of soil sample was taken from the location and then mixed and put in a plastic bag. One gram of soil weighed for bacterial isolation (Chaiharn and Lumyong 2009).

\section{Isolation of phosphate solubilizing bacteria}

Ten grams of rhizosphere soil samples were weighed and put into $90 \mathrm{~mL}$ sterile physiological saline solution
$0.85 \% \mathrm{NaCl}$. Dilution performed from $10^{-1}$ to $10^{-6}$. The sample inoculated in Duplo at $10^{-4}, 10^{-5}, 10^{-6}$ dilution on solid Pikovskaya medium, then incubated at room temperature for three days (Susila et al. 2016). Colonies that formed clear zones on the Pikovskaya medium were marked. Then, the solubilization index (SI) of each colony measured with a ratio (Mubarik et al. 2014):

$$
\begin{aligned}
& \text { Phosphate Solubilization Index } \\
& =\frac{\text { diameter of the clear zone-diameter of the colony }}{\text { the diameter of the colony }}
\end{aligned}
$$

\section{Quantitative estimation of phosphate solubilizing activity}

Bacterial isolates were grown in $50 \mathrm{~mL}$ liquid Pikovskaya medium and incubated for 48 hours. One $\mathrm{mL}$ of inoculant was transferred into $100 \mathrm{~mL}$ liquid Pikovskaya medium and incubated. Every 24 hours (in 6 days), $1.5 \mathrm{~mL}$ of culture centrifuged. Centrifugated to separate the supernatant. One mL of supernatant was reacted with 2.5 $\mathrm{mL}$ of sodium molybdate $2.5 \%$ and $1 \mathrm{~mL}$ of hydrazine sulfate $0.3 \%$ and heated for 10 minutes. A positive reaction was determined by the color change of the mixture from white into the blue. The mixed solution was measured using a spectrophotometer at the $830 \mathrm{~nm}$ wavelength (Lynn et al. 2013).

\section{Screening of Indole Acetic Acid (IAA) producing bacterial isolate}

Bacterial isolates indicating phosphate solubilizing activity underwent screening for the potential for indole acetic acid (IAA) production. One loop of the selected bacterial isolate was inoculated in $50 \mathrm{ml} \mathrm{NB}$ medium added with $1.0 \mathrm{mM}$ L-tryptophan and incubated in a shaking incubator until its cell density reached $10^{8} \mathrm{cells} / \mathrm{ml}$. One milliliter of bacterial culture was grown on $100 \mathrm{ml} \mathrm{NB}$ medium and incubated at an agitation speed of $100 \mathrm{rpm}$. Estimation of IAA was conducted by collecting $1 \mathrm{~mL}$ of supernatant and pouring $4 \mathrm{~mL}$ of Salkowski reagent into it. The culture incubated in a dark room for 15 minutes. The level of IAA production was measured using a spectrophotometer at $520 \mathrm{~nm}$ (Mahmoud et al. 2015).

\section{Hypersensitivity assay}

Bacterial hypersensitive reaction to tobacco (Nicotiana tobaccum L.) was examined through suspension injection using a $1 \mathrm{~mL}$ syringe. The response was observed from $24 \mathrm{~h}$ to $72 \mathrm{~h}$ after inoculation time. A positive reaction was indicated by the appearance of brown spots or necrotic symptoms around the injected area, whereas the absence of symptoms of necrosis considered a negative reaction (Abdallah et al. 2016).

\section{Antagonist within isolate assay}

Bacterial culture was grown in NB for 24 hours. $400 \mu \mathrm{L}$ of culture put in a Petri dish containing a semi-solid nutrient agar medium. Wells made using a sterile straw on the homogeneous culture so that other isolates can be tested. Isolates and sterile aqua dest were used as a negative control, while kanamycin $(1 \mathrm{mg} / \mathrm{mL})$ used as a positive 
control. 15-20 $\mu \mathrm{L}$ of kanamycin was dropped onto the culture and incubated for 24 hours at room temperature (Fitriyanti et al. 2017).

\section{Bacterial identification}

Morphological and physiological identification of bacteria

Bacterial identification performed by observing the morphological shape of the colony, gram staining, and physiological testing. The observation of the colony morphology included the shape, margin, elevation, and color of the colony. Gram staining conducted to investigate the type and shape of the bacterial cell (Hadioetomo 1993). Physiological testing used Microbact 12A/12E or 24E Kit. Wells on the kit contained testing media. A hundred $\mu \mathrm{l}$ of bacterial suspension was dripped into the wells. Then, the Microbact incubated at $37{ }^{\circ} \mathrm{C}$ for 24 hours. Number seven well on the Microbact added with two drops of Nitrate A and $B$ reagent, while number eight well on the Microbact added with two drops of Indole Kovacs. VP I and VP II were dripped onto number ten well, and TDA was dripped onto number twelve well. Carbohydrate fermentation testing on Microbact twelve B conducted without the addition of a reagent. Reading for positive and negative results was performed by comparing the color table (Oxoid, 2004), while bacterial identification conducted using the Bergeys Manual of Determinative Bacteriology ninth ed (Holt et al. 2000).

\section{Isolation of bacterial genomic DNA}

Bacterial culture $(1.5 \mathrm{~mL})$ was collected and move into an Eppendorf $1.5 \mathrm{ml}$ tube, then centrifuged at $8000 \mathrm{rpm}$ for 10 minutes. The supernatant was separated, and the pellet cleaned with STE buffer (composition: $0.3 \mathrm{M}$ sucrose; 25 $\mathrm{mM}$ Tris-HCL; $25 \mathrm{mM}$ EDTA.2Na $\mathrm{pH} 8$ ), centrifuged at $8000 \mathrm{rpm}$ for 10 minutes. The pellet rinsed three times. The supernatant was discarded and added with $200 \mu \mathrm{L}$ STE buffer and $45 \mu \mathrm{L}$ lysozyme $(20 \mathrm{mg} / \mathrm{mL})$, shaken slowly, and incubated at $55^{\circ} \mathrm{C}$ for an hour until protoplasts there formed. $20 \mu \mathrm{L}$ of proteinase- $\mathrm{K}(20 \mathrm{mg} / \mathrm{mL})$ was added into the solution and incubated at $55^{\circ} \mathrm{C}$ for 60 minutes. After that, $400 \mu \mathrm{L}$ of CTAB $10 \%$ was added into $0.7 \mathrm{M} \mathrm{NaCl}$ and incubated at $65{ }^{\circ} \mathrm{C}$ for 30 minutes. Then, a $1 \mathrm{x}$ volume of 1 phenol: chloroform $(25: 24)$ was poured into the solution and centrifuged for 10 minutes. The clear phase was transferred into a new tube and added with a $0.6 \mathrm{x}$ volume of isopropyl alcohol and $20 \mu \mathrm{L}$ sodium acetate, incubated at $-20^{\circ} \mathrm{C}$ overnight. The solution centrifuged at $12000 \mathrm{rpm}$ for 10 minutes. The supernatant removed and 1 $\mathrm{mL}$ pellets washed using alcohol $70 \%$. The DNA was let dry for an hour so that the alcohol removed. After that, it was dissolved into $50 \mu \mathrm{L}$ sterile $\mathrm{ddH}_{2} \mathrm{O}$. The result of the DNA isolation stored at a temperature of $4^{\circ} \mathrm{C}$ or- $20{ }^{\circ} \mathrm{C}$ (Modified from Sambrook and Russel 2001).

\section{Amplification of bacterial isolate 16S rRNA gene \\ Amplification of bacterial isolate 16S rRNA gene was conduct using polymerase chain reaction (PCR) and}

prokaryotic specific primers (Marchesi et al. 1998), which are forward $63 \mathrm{f}\left(5^{\prime}\right.$-CAG GCC TAA CAC ATG CAA GTC-3') and reverse 1387r (5'-GGG CGG WGT GTA CAA GGC-3'). PCR reaction was composed of $0.5 \mu \mathrm{L}$ of La Taq DNA polymerase enzyme, $2 \times 25 \mu \mathrm{L}$ of GC buffer, $8 \mu \mathrm{L}$ of dNTP mixture, $1.5 \mu \mathrm{l}$ of primer $(10 \mathrm{pmol}), 9.5 \mu \mathrm{L}$ of $\mathrm{ddH}_{2} \mathrm{O}$, and $4 \mu \mathrm{L}$ of DNA template. The PCR conditions used were pre-denaturation $\left(94^{\circ} \mathrm{C}, 4\right.$ minutes), denaturation (94 ${ }^{\circ} \mathrm{C}, 45$ seconds), annealing $\left(55^{\circ} \mathrm{C}, 1\right.$ minute), elongation (72 ${ }^{\circ} \mathrm{C}, 1$ minute 10 seconds), and post PCR $\left(72{ }^{\circ} \mathrm{C}, 7\right.$ minutes), 30 cycles in total. The separation of DNA was conducted on mini-gel Electrophoresis Equipment using $1 \%$ agarose gel, 75 Volt for 45 minutes. DNA visualization was performed on UV transilluminator using Ethidium Bromide (EtBr) stain.

\section{DNA sequencing and phylogenetic tree construction}

Raw data on sequencing were trimmed and assembled using ChromasPro program version 1.5. The assembled data were analyzed using BLAST containing gene registered at the NCBI/ National Center for Biotechnology Information (http://www.ncbi.nlm.nih.gov/BLAST/). The result of the BLAST sequencing analysis considered as species with the closest kinship. The species strain type from GenBank data at the NCBI. The DNA sequence was aligned using MEGA 6.1 program (Tamura et al. 2011). Phylogenetic tree showing kinship of the Xyl_22 bacterial isolates constructed using Actinomycete, while other nonactinomycete microbes were analyzed using the NeighborJoining Tree method with 1000 bootstrap replications (Felsenstein 1985).

\section{RESULTS AND DISCUSSION}

\section{Isolation of phosphate solubilizing and IAA producing bacteria}

Based on the result of the bacterial isolation, eight bacterial isolates found to be able to grow on a solid Pikovskaya medium. These bacterial isolates purified for identification of colony shape, margin, elevation, and color. Table 1 shows that the colony shape of the eight isolates was dominated by circular shape, while the margin was mostly entire and the elevation was mostly flat. Six isolates were white color and two isolates were cream. The eight isolates were assumed to have the ability to dissolve phosphate, indicated by the clear zones formed around the bacterial colony.

The ability of the isolates to solubilize phosphate was re-examined qualitatively by dripping bacterial cultures on solid Pikovskaya medium. The bacterial phosphate solubilizing activity expressed in the phosphate solubilization index (SI). Six isolates were proven to be able to form clear zones around the bacterial colonies on the Pikovskaya medium (Figure 1). 
Table 1. Characteristics of bacterial isolate

\begin{tabular}{lllll}
\hline \multirow{2}{*}{ Isolate code } & \multicolumn{4}{c}{ Morphological characteristics } \\
\cline { 2 - 5 } & Shape & Margin & Elevation & Color \\
\hline Arj1 & Circular & Entire & Convex & Milky white \\
Arj2 & Circular & Entire & Flat & Cream \\
Arj3 & Circular & Entire & Flat & White \\
Arj4 & Circular & Entire & Flat & White \\
Arj5 & Circular & Entire & Umbonate & Transparent \\
Arj6 & Irregular & Undulate & Flat & Transparent \\
Arj7 & Circular & Entire & Convex & Transparent \\
Arj8 & Concentric & Entire & Cream \\
\hline
\end{tabular}

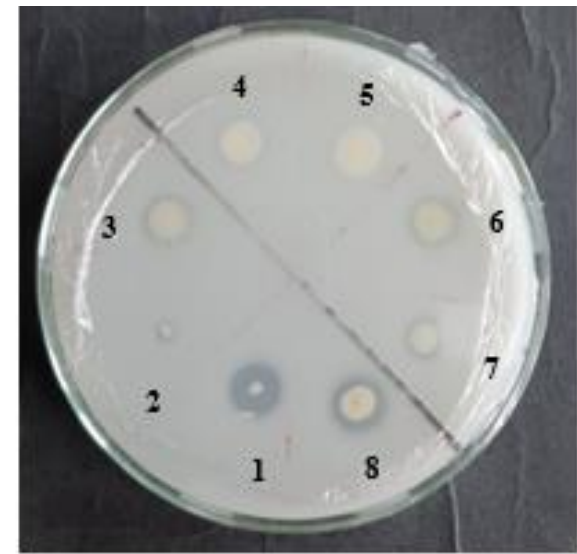

Figure 1. Testing the ability of eight isolates to solubilize phosphate on Pikovskaya medium (1) Arj1, (2) Arj2, (3) Arj3, (4) Arj4, (5) Arj5, (6) Arj6, (7) Arj7, and (8) Arj8

Pikovskaya medium normally contains tricalcium phosphate and is a turbid white color. Therefore, isolates that can grow and form clear zones on the medium are isolates that can dissolve phosphate elements. Similarly, Atekan et al. (2014) reported that the ability of isolates to dissolve phosphate characterized by the formation of clear zones around bacterial colonies. Clear zones are an indication of bacterial activity in dissolving phosphate contained on the medium.

The solubilization index (SI) of each bacterial isolate ranged from 0.125 to 0.61 (Table 2). Solubilization index (SI) may vary depending on the ability of bacterial isolates to secrete organic acids. Phosphate solubilizing mechanisms are often associated with the release of organic acids by phosphate solubilizing bacteria (Ricardshon et al. 2009). Microorganisms produce different organic acids, such as acetate, lactate, malate, oxalate, succinate, citrate, gluconate, and ketogluconate. Organic acids can form stable compounds through reactions with calcium $(\mathrm{Ca})$, iron (Fe), and aluminum (Al) (Gyaneshwar et al. 2002). Besides organic acids, phosphate solubilization released by phosphatase and phytase enzymes. The availability of organic phosphate depends on microbial activity to produce enzymes. Phosphatase enzymes play an important role in organic phosphate mineralization (Joner et al. 2000; Mubarik et al. 2014).
Table 2. Characteristics of isolate growth on the Pikovskaya medium.

\begin{tabular}{lccc}
\hline Isolate & $\begin{array}{c}\text { Phosphate } \\
\text { solubilizing } \\
\text { activity }\end{array}$ & $\begin{array}{c}\text { Solubilization } \\
\text { Index (SI) }\end{array}$ & $\begin{array}{c}\text { Concentration } \\
\text { IAA (ppm) }\end{array}$ \\
\hline Arj1 & + & 3.5 & 0 \\
Arj2 & + & 0.33 & 9.73 \\
Arj3 & + & 0.125 & 24.35 \\
Arj4 & - & - & 0 \\
Arj5 & - & - & 36.21 \\
Arj6 & + & 0.125 & 0 \\
Arj7 & + & 0.16 & 0 \\
Arj8 & + & 0.61 & 38.39 \\
\hline Note: (+) colony showed phosphate solubilizing activity, (-) \\
colony did not show phosphate solubilizing activity
\end{tabular}

Morphological characterization of potential bacteria performed to investigate phosphate solubilizing activity and IAA production of the bacteria. The result of the analysis showed that L-tryptophan as the precursor in the NB medium was turned into IAA after overnight incubation. The highest IAA production was showed by isolate Arj3, Arj5, and Arj8 (24.35 ppm, $36.21 \mathrm{ppm}$, and 38.39 ppm, respectively). Serratia marcescens KAHN 15.12 could optimally synthesize IAA (22.37 ppm) at 18 hours (Astriani et al. 2016). The ability of rhizospheric bacteria to produce $15.20 \mathrm{mg} / \mathrm{L}$ IAA can affect the growth of primary soybean roots (Wahyudi et al. 2011).

Variation in the IAA level produced by bacteria is caused either by the environmental condition or the main precursor used for IAA biosynthesis (Patten and Glick 2002). Tryptophan, as an inducer, can synthesize IAA in bacterial cultures (Tsavkelova et al. 2006; Mohite 2013). Indole-3-acetamide (IAM) identified as the IAA biosynthesis pathway involves tryptophan-2monooxygenase (IaaM) enzyme and IAM hydrolase enzyme (Spaepen and Vanderleyden 2011).

\section{Quantitative estimation of bacterial phosphate solubilizing activity}

Two isolates (Arj3 and Arj8) that showed multiple potentials to dissolve phosphate and synthesize IAA selected for quantitative analysis of phosphate solubilizing activity (Figure 2). Arj3's phosphate solubilizing activity was at the highest on day-2 (51.45 mg/L), and Arj8 showed the highest $\mathrm{P}$ solubilizing activity on day-3 and day-5 
(75.39 and $74.33 \mathrm{mg} / \mathrm{L}$, respectively). The bacterial phosphate solubilizing mechanism was based on $\mathrm{Ca}$ phosphate (tricalcium phosphate) solubilizing activity in liquid culture. The concentration of phosphate dissolved depends on sources of phosphate, microorganism growth, and condition of culture (Ricardson et al. 2009). Phosphate solubilizing activity in rhizobacteria liquid culture containing $1.5 \%$ tricalcium phosphate reached its highest level on day-5 $(27.10 \mu \mathrm{g} / \mathrm{mL})$ at an incubation temperature of $37{ }^{\circ} \mathrm{C}$ (Patel et al. 2017). After 7-day incubation, bacterial cultures could dissolve organic phosphate $\mathrm{Ca}_{3}$ $\left(\mathrm{PO}_{4}\right)_{2} \cdot \mathrm{Al}_{3}\left(\mathrm{PO}_{4}\right)_{2}$ and phosphate rock in liquid medium (18.59 $\mathrm{L}^{-1}, 18.3 \mathrm{~L}^{-1}, 5.68 \mathrm{~L}^{-1}$ ) (Widawati 2011). Tricalcium phosphate $\mathrm{Ca}_{3}\left(\mathrm{PO}_{4}\right)_{2}$ contained in the Pikovskaya medium was broken down by Ca-phosphate solubilizing rhizobacteria into the available forms (Richardson et al. 2009).

\section{Hypersensitivity Assay and Antagonist Within Isolate}

The two isolates injected on tobacco leaves did not indicate any necrotic symptoms until the fourth day (similar to the negative control reaction) (Figure 3c-d). The leaf injected with isolate Arj3 showed brown and yellow spots on four replicate injection sites as it entered day 14 (Figure 3e). The changes that occurred in isolate Arj3 are the same as those experienced by pathogenic bacteria on positive control. The found was consistent with Klement and Godman (1967), who explained that every time a pathogen isolate attacks the host, the tissue would show a necrosis reaction to prevent further spread of the pathogen. Isolate Arj8 did not show any form of plant defense against pathogens, so this isolate can be considered eco-friendly and thus can as a biofertilizer candidate.

The result of the hypersensitivity assay showed that isolate Arj3 was less effective for fertilizer application due to its pathogenic properties. Therefore, this isolate was excluded from further testing. On the other hand, isolate Arj8 was selected for further testing because it indicated multiple potentials to dissolve phosphate and produce IAA and was not pathogenic to plants. Antagonist within isolate assay of isolate Arj8 can be seen in Figure 4. There was no inhibitor zone shown in the picture as also occurred in positive control using kanamycin (Figure 4). This finding suggests that isolate Arj8 does not exude metabolites nor produce compounds that can inhibit the growth of other isolates, so it called that isolate Arj8 is safe to form a microbial consortium with other superior isolates.

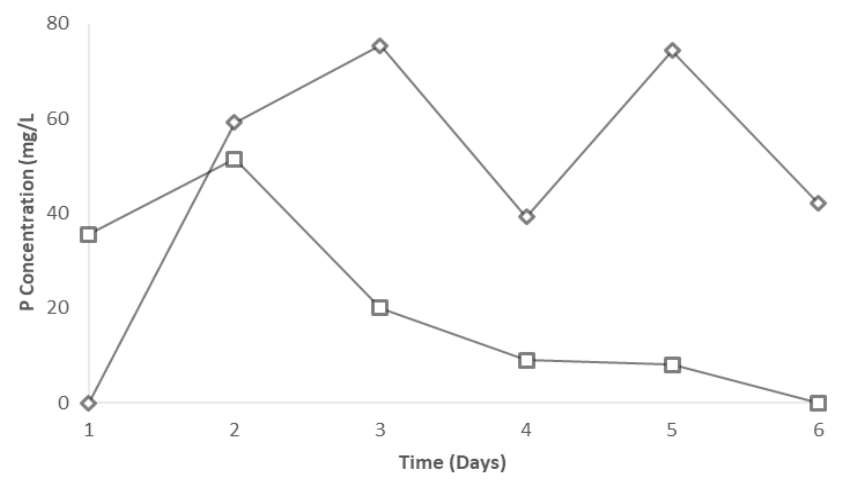

Figure 2. $P$ solubilizing concentration. $-\square-$ isolate Arj3,,isolate Arj8

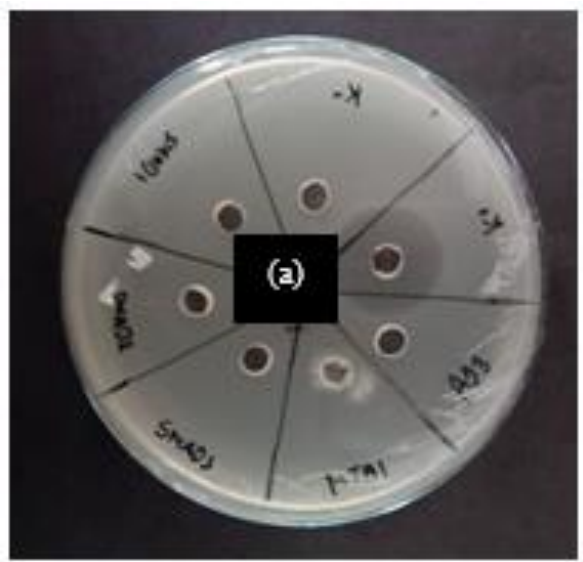

Figure 4. Antagonist Transisolate Assay on semisolid nutrient agar media. Isolate Arj8 (a), positive control (K+) using kanamycin, negative control (K-) using sterile aquadest

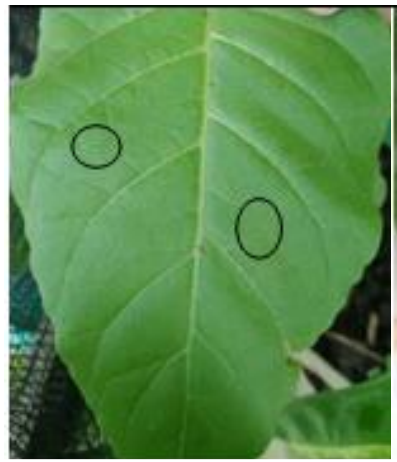

A

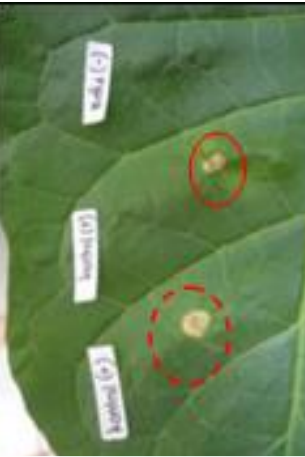

B

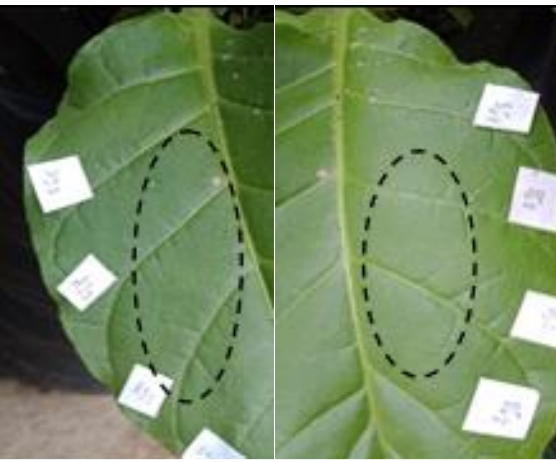

C

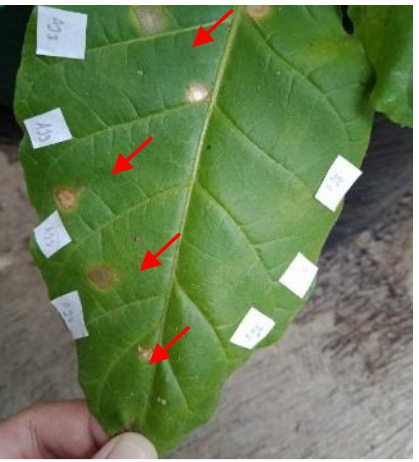

$\mathbf{E}$

Figure 3. Hypersensitivity Assay on day-4. Negative (A), Necrotic Symptoms (B), ), isolate Arj3 after four days (C), isolate Arj8 after four days (D), treatment after 14 days (isolate Arj3 on the left) and (isolate Arj8 on the right) (E), red arrows (+ Necrosis) 


\section{Identification of the selected bacterial isolates}

After bacterial screening conducted in several stages, bacterial identification performed to the selected isolate, namely isolate Arj8. Isolate Arj8 identified as one of the isolates with the highest IAA production and the highest phosphate solubilizing activity. Arj8 colony has a diameter of $1.11 \mathrm{~mm}$ and coccobacilli shape based on negative gram staining (Figure 5). The result of the physiological testing using Microbact on Arj8 showed positive results in motility, lysin, glucose reducing, xylose, citrate, and catalase. Based on the bacterial morphological and physiological identifications, isolate Arj8 shared many similarities with Pseudomonas (Holt et al. 1994). Molecular Identification of isolate Arj8 was performed afterward to find out the accuracy of the species name and the kinship of the isolate towards other bacteria by constructing a phylogenetic tree.

Amplified 16S rRNA gene result indicated a $1300 \mathrm{bp}$ DNA band (Figure 6). The length of the fragment was as expected; therefore, 16S rRNA sequencing was continued to obtain the order of nitrogen bases. The result of the sequencing analysis showed that Arj8 consisted of 1136 base pairs (Figure 7). The data were aligned and analyzed using BLAST and then compared to the DNA GenBank database. The result of the analysis showed that Arj8 shared $100 \%$ similarity with Pseudomonas plecoglossicida and $99.91 \%$ similarity with Pseudomonas putida (Table 4).

The phylogenetic tree constructed will describe the kinship between isolate Arj8 and other bacteria that come from the same clade or the outer group. The phylogenetic tree constructed using the Neighbor-Joining Tree method with 1000x bootstrap replications. It showed that isolate Arj8 was closest in kinship with Pseudomonas plecoglossicida (Figure 8). Pseudomonas is a rhizobacteria genus frequently reported as phosphate solubilizing bacteria that can help repair plant growth mechanisms (Tahir et al. 2015). Pseudomonas has also recognized as the best IAA producing bacteria candidate that can be identified using tryptophan (Pattern and Glick, 2002; Apine and Jadav 2011). Furthermore, research shows that Pseudomonas spp. can bind nitrogen (Li et al. 2017) and control plant pathogens.

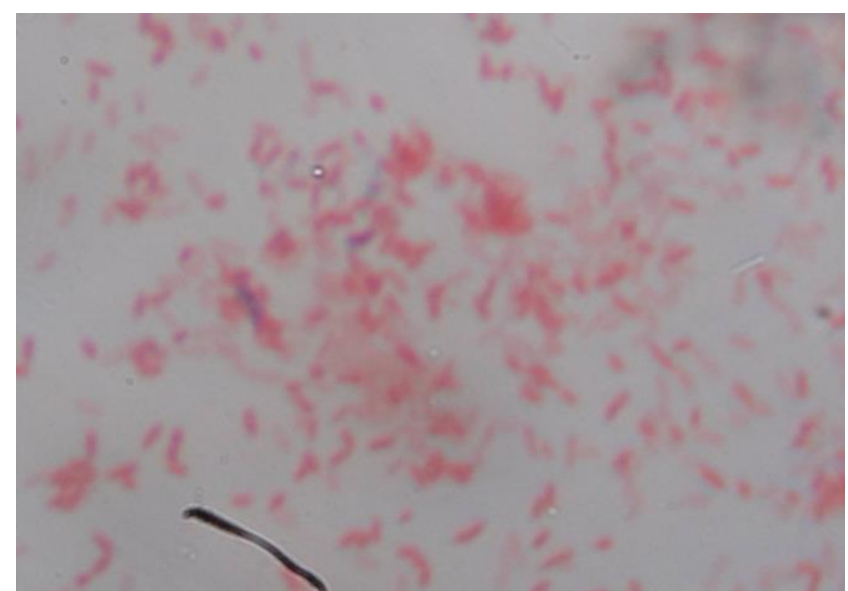

Figure 5. Arj8 Gram Staining at $1000 \mathrm{x}$ magnification

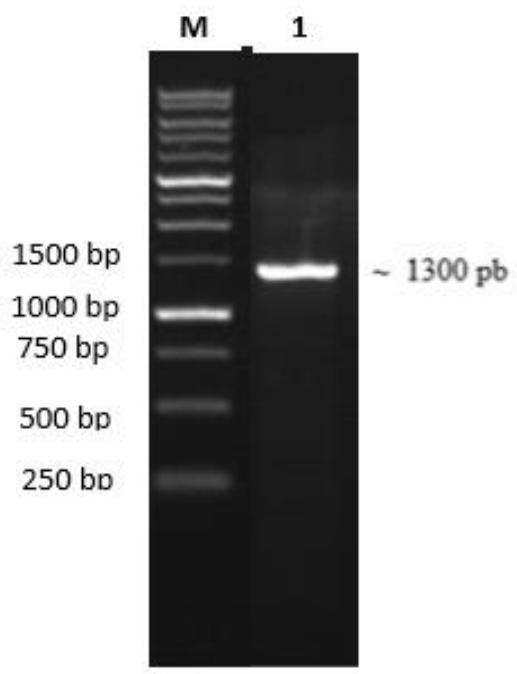

Figure 6. PCR Amplification of the 16S rRNA gene using primer 63f and primer 1378r. Note: M. Marker $1 \mathrm{~kb}, 1$. DNA band of the sample isolate Arj8

GCGAGTTGCAGACCTGACAATCCGAACTGAGAATGGCTTTAAGAGATTAGCTTACTCTCGCGAGTTCGCAACTCGTTGTACCATCCATTGT AGCACGTGTGTAGCCCAGGTCATAAGGGGCATGATGATTTGACGTCATCCCCACCTTCCTCCGGTTTGTCACCGGCAGTCTCACCAGAGTG CCCAACTTAATGCTGGCAACTGATAATAAGGGTTGCGCTCGTTGCGGGACTTAACCCAACATCTCACGACACGAGCTGACGACAACCATGC ACCACCTGTATCCATGTCCCCGAAGGGAACGTCTAATCTCTTAGATTTGCATAGTATGTCAAGACCTGGTAAGGTTCTTCGCGTAGCTTCG AАTTAAACCACATGCTCCACCGCTTGTGCGGGCCCCCGTCAATTCCTTTGAGTTTCAGCCTTGCGGCCGTACTCCCCAGGCGGAATGCTTA ATGCGTTAGCTGCAGCACTGAAGGGCGGAAACCCTCCAACACTTAGCATTCATCGTTTACGGTATGGACTACCAGGGTATCTAATCCTGTT TGCTACCCATACTTTCGAGCCTCAGCGTCAGTTACAGACCAGACAGCCGCCTTCGCCACTGGTGTTCTTCCATATATCTACGCATTTCACC GCTACACATGGAGTTCCACTGTCCTCTTCTGCACTCAAGTTTCCCAGTTTCCGATGCACTTCTTCGGTTGAGCCGAAGGCTTTCACATCAG ACTTAAAAAACCGCCTGCGCTCGCTTTACGCCCAATAAATCCGGACAACGCTTGCCACCTACGTATTACCGCGGCTGCTGGCACGTAGTTA GCCGTGGCTTTCTGGTTAAATACCGTCAATACCTGAACAGTTACTCTCAGATATGTTCTTCTTTAACAACAGAGTTTTACGAGCCGAAACC СTTCTTCACTCACGCGGCGTTGCTCCATCAGACTTTCGTCCATTGTGGAAGATTCCCTACTGCTGCCTCCCGTAGGAGTTTGGGCCGTGTC TCAGTCCCAATGTGGCCGATTACCCTCTCAGGTCGGCTACGTATCATTGCCATGGTGAGCCGTTACCCCACCATCTAGCTAATACCCGGGG GACCATCCAAAAGTGATAGCGAAGGCATCTTT

Figure 7. 16 SRNA gene sequence of isolate Arj8 consisting of 1136 base pairs 
Table 4. The result of 16 SRNA gene sequencing analysis of isolate Arj8 compared to the NCBI (BLASTX) database

\begin{tabular}{|c|c|c|c|c|c|c|}
\hline Description & $\begin{array}{l}\text { Max } \\
\text { score }\end{array}$ & $\begin{array}{l}\text { Total } \\
\text { score }\end{array}$ & $\begin{array}{l}\text { Query } \\
\text { cover }\end{array}$ & $\begin{array}{c}\mathbf{E} \\
\text { value }\end{array}$ & Identity & $\begin{array}{c}\text { Access } \\
\text { number }\end{array}$ \\
\hline $\begin{array}{l}\text { Pseudomonas plecoglossicida strain R19 16S ribosomal RNA } \\
\text { genes, partial sequence }\end{array}$ & 2098 & 2098 & $100 \%$ & 0.0 & $100 \%$ & KJ819577.1 \\
\hline $\begin{array}{l}\text { Pseudomonas putida strain Xh91 16S ribosomal RNA gene, } \\
\text { partial sequence }\end{array}$ & 2093 & 2093 & $100 \%$ & 0.0 & $99.91 \%$ & MK064155.1 \\
\hline $\begin{array}{l}\text { Pseudomonas guariconensis strain LBQSKF6 16S ribosomal } \\
\text { RNA gene, partial sequence }\end{array}$ & 2093 & 2093 & $100 \%$ & 0.0 & $99.91 \%$ & KX364073.1 \\
\hline $\begin{array}{l}\text { Pseudomonas monteilii strain CSR2 16S ribosomal RNA gene, } \\
\text { partial sequence }\end{array}$ & 2093 & 2093 & $100 \%$ & 0.0 & $99.91 \%$ & KJ522791.1 \\
\hline $\begin{array}{l}\text { Pseudomonas taiwanensis } 16 \mathrm{~S} \text { ribosomal RNA gene, partial } \\
\text { sequence }\end{array}$ & 2093 & 2093 & $100 \%$ & 0.0 & $99.91 \%$ & GU124496.1 \\
\hline
\end{tabular}
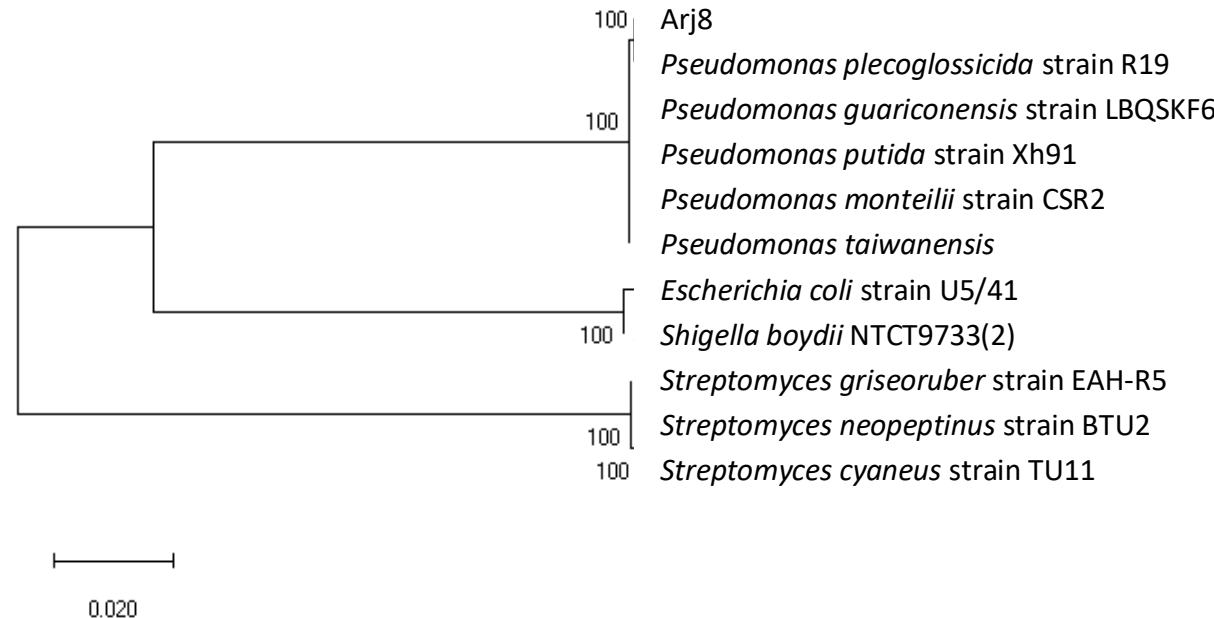

Figure 8. Phylogenetic Tree showing the kinship between isolate Arj8 and other bacteria from the same clade or the outer group. The phylogenetic tree construction was done using the Neighbor-Joining Tree method with 1000x bootstrap 1000x replications

Pseudomonas plecoglossicida is a bacterium that is specifically and genetically related to Pseudomonas putida (Mulet et al. 2010). P. plecoglossicida possesses the characteristics of motile bacteria, which are nonfluorescent, gram-negative, and bacillus. P. plecoglossicida can be used for bioremediation of cypermethrin (Boricha and Fulekar 2009) and degradation of organophosphate (OP) and carbamate pesticide compounds (Chanika et al. 2010). P. plecoglossicida activity in phosphatase mechanisms and phytohormone biosynthesis has not reported. Studies merely found $P$. putida as a plant growthpromoting trigger with several mechanisms including the production of indole acetic acid and siderophore (Patten and Glick 2002; Montiel et al. 2017), phosphate solubilization (Kalayu 2019), bioremediation (Liu et al. 2016), and biopesticides (Chanika et al. 2010). Therefore, this study can provide a new insight related to $P$. plecoglossicida activity as a superior bacterial species that possess multiple potentialities that are to produce IAA hormone and solubilize phosphate. This bacterium needs to be studied further so that it can be used as a biofertilizer candidate in the future.
In conclusion, six bacterial isolates found on the soybean rhizosphere were able to dissolve phosphate, indicated by the formation of clear zones. Among them, there were two isolates, namely isolate Arj3 and Arj8, that showed the highest phosphate solubilizing activity and IAA production. Besides performing the highest phosphate solubilizing activity and IAA production, isolate Arj8 also found to be non-pathogenic to plants. Isolate Arj8 has closely related to Pseudomonas plecoglossicida. The potential of P. plecoglossicida as a phosphate-solubilizing bacterium and an IAA producing bacterium is a novel finding that can contribute to the development of biofertilizers that are environmentally friendly, effective, and efficient in reducing the use of synthetic chemical fertilizers.

\section{ACKNOWLEDGMENTS}

The authors would like to thank DRPM DIKTI for the funding support on Doctoral Dissertation Research with contract no. 074/SP2H/L/DRPM/2019 and the Gogodeso 
village chief as well as Binangun farmers for their kind assistance in collecting soil samples from soybean plantations in Blitar, East Java, Indonesia.

\section{REFERENCES}

Abdallah RA, Trabelsi BM, Nefzi A, Khiareddine HJ, Remadi MD. 2016 Isolation of endophytic bacteria from Withania somnifera and assessment of their ability to suppress fusarium wilt disease in tomato and to promote plant growth. J Plant Microbiol 7 (5): 3-11.

Apine O, Jadhav JP. 2011. Optimization of medium for indole-3-acetic acid production using Pantoea agglomerans strain PVM. J Appl Microbiol 110: 1235-1244.

Astriani M, Mubarik NR, Tjahjoleksono A. 2016. Selection of bacteria producing indole-3-acetic acid and its application on oil palm seedlings (Elaeis guineensis Jacq.). Malays J Microbiol 12 (2): 147 154.

Atekan, Nuraini Y, Handayanto, E, Syekhfani. 2014. The potential of phosphate solubilizing bacteria isolated from sugarcane wastes for solubilizing phosphate. J Degrade Min Land Manag 1 (4): 175-182.

Boricha H, Fulekar MH. 2009. Pseudomonas plecoglossicida as a novel organism for the bioremediation of cypermethrin. Biol Med 1 (4): 1 10.

Chaiharn M, Lumyong S. 2009. Phosphate solubilization potential and stress tolerance of rhizobacteria from rice soil in Nothern Thailand. World J Microbiol Biotechnol 25: 305-314.

Chanika E, Georgiadou D, Soueref E, Karas P, Karanasios E, Tsiropoulos NG, Tzortzakakis EA, Karpouzas DG. 2010. Isolation of soil bacteria able to hydrolyze both organophosphate and carbamate pesticides. Bioresour Technol 102: 3184-3192.

Fallo G, Mubarik NR, Triadiati. 2015. Potency of auxin producing and phosphate solubilizing bacteria from dryland in rice paddy field. Res J Microbiol 10 (6): 246-259.

Felsenstein J. 1985. Confidence limits on phylogenies: an approach using the bootstrap. Evolution 39 (4): 783-791.

Fitriyanti D, Mubarik NR, Tjahjoleksono A. 2017. Characterization of phosphate solubilizing bacteria and nitrogen-fixing bacteria from limestone mining region. Malays J Microbiol 13 (3): 147-155.

Gang S, Sharma S, Saraf M, Buck M, Schumacher J. 2019. Analysis of Indole-3-Acetic-Acid (IAA) production in Klebsiella by LC-MS/MS and the salkowski method. Bio-Protocol 9 (9): 1-9.

Glick BR. 2012. Plant growth-promoting bacteria: mechanisms and applications. Scientifica 963401: 1-15.

Gyaneshwar P, Kumar NG, Parekh LJ, Poole PS. 2002. Role of soil microorganism in improving $\mathrm{P}$ nutrition of plants. Plant Soil 245: 83 93.

Hadioetomo RS. 1993. Basic Microbiology in Practice. PT. Gramedia, Jakarta. [Indonesia]

Hasan N, Suryani E, Hendrawan R. 2015. Analysis of soybean production and demand to develop strategic policy of food self-sufficiency: a system dynamics framework. Computer Sci 72: 605-612.

Hungria M, Nogueira MA, Araujo RS. 2015. Soybean seed co-inoculation with Bradyrhizobium spp. and Azospirillum brasilense: A New biotechnological tool to improve yield and sustainability. Am J Plant Sci 6: 811-817.

Holt JG, Noel RK, Peter HA, James TS, Stanley TW. 2000. Bergey's Manual of Determinative Bacteriology. 9th ed. Lippincott William \& Wilkins, New York.

Jing H, Strader LC. 2019. Interplay of auxin and cytokinin in lateral root development. Intl J Mol Sci 20 (486): 1-12.

Joner EJ, Aarle IM, Vosatka M. 2000. Phosphatase activity of extraradical arbuscular mycorrhizal hyphae: A review. Plant Soil 226: 199210.

Kalayu G. 2019. Phosphate solubilizing microorganism: promising approach as biofertilizers. Intl J Agron 2019: 4917256. DOI $10.1155 / 2019 / 4917256$.

Klement Z, Goodman RN. 1967. The hypersensitive reaction to infection by bacterial plant pathogens. Phytopathology 5: 17-44.

Kumar K. 2014. Characterization bio-formulation development and shelflife studies of locally isolated bio-fertilizer strains. Octa J Environ Res 2 (1): 32-37.

Kristanti NE, Rahmawati F, Maksum M. 2017. Analysis of productivity of soybean [Glycinemax (L.) Merr.] for production for farmers in
Indonesia. International Conference on Agro-Industry. Bangkok, Thailand, 9-11 November 2016. [Indonesian]

Liu J, Tan L, Wang J, Ni H, Li L. 2016. Complete biodegradation chlorpyrifos by engineered Pseudomonas putida cells expressing surface-immobilized laccases. Chemosphere 157: 200-207.

Li Z, Zu C, Wang C, Yang J, Yu H, Wu H. 2016. Different responses of rhizosphere and non-rhizosphere soil microbial communities to consecutive Piper nigrum L. monoculture. Nat Sci Rep 6: 35825.

Li HB, Singh RK, Singh P, Song QQ, Xing YX, Yang LT, Li YR. 2017. Genetic diversity of nitrogen-fixing and plant growth-promoting Pseudomonas species isolate from sugarcane rhizosphere. Front Microbiol 8: 1268.

Li M, Guo R, Yu F, Chen X, Zhao H, Li H, Wu J. 2018. Indole-3-Acetic Acid biosynthesis pathways in the plant beneficial bacterium Arthrobacter pascens ZZ21. Intl J Mol Sci 19 (443): 1-15.

Lynn TM, Win HS, Kyaw EP, Latt ZK, Yu SS. 2013. Characterization of phosphate solubilizing and potassium decomposing strains and study on their effects on tomato cultivation. Intl J Innov Appl Stud 3 (4): 959-966.

Mahmoud W.Y, Antony I, Glick B.R. 2015. Isolation and characterization of endophytic plant growth-promoting bacteria from date palm tree (Phoenix dactylifera L.) and their potential role in salinity tolerance. Antonie van Leeuwenhoek 107: 1519-1532.

Majda M, Robert S. 2018. The role of auxin in cell wall expansion. Intl J Mol Sci 19 (951): 1-21.

Marchesi JR, Sato T, Weightman AJ, et al. 1998. Design and evaluation of useful bacterium-specific PCR primers that amplify genes coding for bacterial 16S rRNA. Appl Environ Microbiol 64: 795-799.

Mubarik NR, Wibowo RH, Angraini E, Mursyida E, Wahdi E. 2014. Exploration of bacterial diversity at Cirebon quarry [Final Report]. Quarry Life Award Project, Indonesia.

Mulet M, Lalucat J, Valdes EG. 2010. DNA sequence-based analysis of the Pseudomonas species. Environ Microbiol 12 (6): 1513-1530.

Mohite B. 2013. Isolation and characterization of indole acetic acid (IAA) producing bacteria from rhizospheric soil and its effect on plant growth. J Soil Sci Plant Nutr 13 (3): 638-699.

Montiel LGH, Contreras CJC, Amador BM, Hermandez LV, Aguilar Q, Contreras. 2017. Efficiency of two inoculation methods of Pseudomonas putida on growth and yield of tomato plants. J Soil Sci Plant Nutr 17 (4): 1003-1012.

Nautiyal CS. 1999. An efficient microbiological growth medium for screening phosphate solubilizing microorganisms. FEMS Microbiol Lett 170 (1): 265-270.

Patten CL, Glick BR. 2002. Role of Pseudomonas putida indole acetic acid in development of the host plant root system. Appl Environ Microbiol 68 (8): 3795-3801.

Patel P, Shah R, Modi K. 2017. Isolation and characterization of plant growth-promoting potential of Acinetobacter sp. RSC7 isolated from Saccharum officinarum cultivar Co 671. J Exp Biol Agric Sci 5 (4): 483-491.

Putra AB, Mukaromah A, Wibowo NC. 2017. Analysis of soybean production to achieve soybean self-sufficiency using system dynamics approach. International Joint Conference on Science and Technology, Ayodya Resort Nusa Dua Bali 27-28 September 2017. [Indonesian].

Qin H, Huang R. 2018. Auxin controlled by ethylene steers root development. Intl J Mol Sci 19 (3656): 1-13.

Richardson A, Barea JM, Ann MM, Combaret CP. 2009. Acquisition of phosphorus and nitrogen in the rhizosphere and plant growth promotion by microorganism. Plant Soil 321: 305-339

Sambrook J, Russell DW. 2001. Molecular Cloning a Laboratory Manual. $3^{\text {rd }}$ ed. Cold Spring Harbor Laboratory Pr., New York.

Singh, I. 2018. Plant growth-promoting rhizobacteria (PGPR) and their various mechanisms for plant growth enhancement in stressful conditions: a review. Eur J Biol Res 8 (4): 191-213.

Solomon, C.B, and Bradley, K.W. 2014. Influence of application timings and sublethal rates of synthetic auxin herbicides on soybean. Weed Technol 28: 454-464.

Spaepen S, Vanderleyden J. 2011. Auxin and Plant-Microbe Interactions. Cold Spring Harbor Laboratory Press, New York.

Susila KD, Sudana IM, Ristiati NP, Adnyana IM. 2016. Phosphatase activity and phosphate solubilizing rhizobacteria in volcanic soils of Pancasari, Bali. Intl J Biosci Biotechnol 4 (1), 39-48.

Tahir M, Mirza MS, Hameed S, Dimitrov MR, Smidt H. 2015. Cultivation-based and molecular assessment of bacterial diversity in 
the rhizos heath of Wheat under different crop rotations. Plos One 10 (6): e0130030. DOI: 10.1371/journal.pone.0130030.

Tawaraya K, Horie R, Shinano T, Wagatsuma T, Saito K, Oikawa A. 2014. Metabolite profiling of soybean root exudates under phosphorus deficiency. Soil Sci Plant Nutr 60: 679-694.

Tsavkelova EA, Klimova SY, Cherdyntseva T A, Netrusov AI. 2006. Microbial producers of plant growth stimulators and their practical use: a review. Appl Biochem Microbiol 42 (2): 117-126.

Tsuno Y, Fujimatsu T, Endo K, Sugiyama, Yazaki K. 2018 Soyasaponins: A new class of root exudates in soybean (Glycine max). Plant Cell Physiol 59 (2): 366-375.

Wahyudi AT, Astuti RP, Widyawati A, Meryandini A. 2011 Characterization of Bacillus sp. strains isolated from rhizosphere of soybean plants for their use as potential plant growth for promoting Rhizobacteria. J Microbiol Antimicrob 3 (2): 34-40.
Weil RR, Brady NC. 2017. Phosphorus and potassium. In: The Nature and Properties of Soils. 15th ed. Pearson, Columbus, OH, USA.

Wei Y, Zhao Y, Shi M, Cao Z, Lu Q, Yang T, Fan Y, Wei Z. 2017. Effect of organic acids production and bacterial community on the possible mechanism of phosphorus solubilization during composting with enriched phosphate-solubilizing bacteria inoculation, Bioresour Technol. DOI: 10.1016/j.biortech.2017.09.092.

Widawati, S. 2011. Phosphate solubilization by bacteria isolated from Laki island coastal ecosystem. Biodiversitas 12 (1): 17-21.

Zainuri A, Wardhono A, Sutomo, Ridjal. 2015. Competitiveness improvement strategy of soybean commodity: study of food security in East Java-Indonesia. Agris on-line Papers in Economics and Informatics 3: 99-106. 